\title{
Том \\ Pharmaceutical influencers on Instagram and their communication during the Covid-19 pandemic crisis
}

\author{
Zahaira Fabiola González Romo, Sofia Iriarte Aguirre and \\ Irene García Medina
}

\begin{abstract}
Today, thanks to the consolidation of Internet, users have access to many sources of information on health issues. On social networks, there are profiles of health professionals who share content that generates credibility when published by specialists who are knowledgeable in the sector. These profiles include pharmaceutical professionals who disseminate and create content based on scientific knowledge. Pharmaceutical influencers on Instagram have an informative role on health, nutrition and cosmetic dermatology issues. This research aims to learn about the communication management of these influencers during the Coronavirus crisis in Spain and how they have modified their habitual discourse, as well as seeking to identify the formats of their publications that generate greater engagement and conversions among their followers.
\end{abstract}

Keywords

DOI

Context
Science and media; Science communication in the developing world; Science communication: theory and models

https://doi.org/10.22323/2.19050204

Submitted: 10th May 2020

Accepted: 7th August 2020

Published: 30th September 2020

In the field of marketing and advertising, the theory of opinion leadership has had many implications in the sector [Weimann et al., 2007]. Today, these opinion leaders are found on social media and are perceived as influential figures within their communities. The figure of the influencer or prescriber can be defined as those leaders of digital opinion in social networks that transmit information to an unknown mass audience [Uzunoğlu and Kip, 2014; Gräve, 2017].

Along the same lines, IAB Spain [2019] defines influencer marketing as a relatively new business model where opinion leaders, called influencers, are individuals who have certain knowledge and experience on a particular topic. These digital opinion leaders have the ability to influence the attitudes, decisions and behavior of their audience through the activities they carry out on social networks [Lyons and Henderson, 2005; Watts and Dodds, 2007]. 
Today, thanks to the consolidation of the Internet, users have access to many sources of information on health issues. On social networks, there are profiles of health professionals who share content that generates credibility when published by specialists who are knowledgeable in the sector. These profiles include pharmaceutical professionals who disseminate and create content based on scientific knowledge. Pharmaceutical influencers on Instagram have an informative role on health, nutrition and cosmetic dermatology issues.

This study analyses how Spanish pharmaceutical influencers have managed communication during the COVID-19 pandemic crisis. The Instagram posts made by 6 pharmaceutical professionals considered influential figures in the sector were analysed observing what type of content is published in terms of subject matter, what formats and which publications generate the most interaction. As a complement to this study, it is also observed if the number of followers of each selected prescriber increases during the observation period.

\subsection{Word of mouth communication and its evolution to eWOM}

The concept of word-of-mouth (WOM) has been defined over the years as one of the oldest ways of sharing information [Dellarocas, 2003]. The influence of WOM on consumer purchasing decisions has been investigated within marketing and consumer behavior since the 1960s [Feick and Price, 1987; Goldsmith and Clark, 2008].

According to one of the first investigations carried out by sociologists Katz and Lazarsfeld [1955], it was discovered that word-of-mouth (WOM) was one of the factors that had the most influence on the purchase of household and food products, exceeding the influence of press and magazine ads, radio advertising or personal selling.

Katz and Lazarsfeld [1955] defined the concept as the exchange of information about products, services or things between consumers in such a way that it plays a fundamental role in behavior and the change of attitudes about them.

When television was becoming the main media of communication in the late 1960s [Marhuenda García, 2016], a series of investigations continued to demonstrate the importance of personal communication as an essential factor in the purchase decision process [Arndt, 1967; Engel, Blackwell and Kegerreis, 1969].

In 1967, the Columbia Graduate School of Business professor Johan Arndt conducted a monograph for the Advertising Research Foundation called "Word of Mouth Advertising" [Keller, 2007]. After reviewing and analyzing 147 studies in the sociology, psychology and marketing literature, the author concluded that "WOM emerges as one of the most important sources, if not the most important (emphasis in the original text) source of information for the consumer "[Arndt, 1967].

Arndt [1967] defines WOM as that personal and verbal communication in relation to a product, service or brand in which the recipient of the message perceives the information of the sender as an action without commercial purposes. 
Two characteristics emerge from this definition [Villanueva and Armelini, 2007]:

- For the communication process to take place, the two parties must be physically present.

- The issuer must be perceived by the recipient as someone outside the commercial organization. For the receiver's suggestion to be credible, it must come from a natural dialogue between both people. The sender must have knowledge of the product and the receiver must have the need to know.

Along the same lines, Harrison-Walker [2001] defines the WOM as "Informal person-to-person communication between a perceived non-commercial communicator and a recipient regarding a brand, product, organization or service" (p. 63). Later other authors provide a definition similar to that proposed by Harrison-Walker [2001], Litvin, Goldsmith and Pan [2008] describe the word-of-mouth as that existing communication between consumers about a brand, service or product where the sources information are considered independent and without commercial purposes.

Brown, Broderick and Lee [2007] assure that this personal exchange between consumers gives access to information about a product or service that goes beyond the messages launched by the brands and this indirectly affects the consumer's decision.

According to Keller [2007] and Bampo et al. [2008] credibility in the issuer comes from the knowledge, the veracity and the relationship of trust that exists between it and the receiver. The more known and identifiable the sender is perceived, the more credibility will be generated in the message received by the receiver.

Not only credibility in the issuer plays an important role in WOM communication. Gladwell [1994] assures that for the process to be effective, three simple rules must be followed:

- The message must be attractive. There are specific ways and means to make a message memorable and attractive.

- The messages should influence those groups of people who are well related to each other and who have a great capacity to influence others.

- The context: the social context where a message is produced is relevant for the WOM process to take place.

The authors Daugherty and Hoffman [2014] also affirm that WOM or word of mouth is considered as one of the factors that most influences consumer behavior. This power of influence is especially relevant when it comes to intangible products that cannot be evaluated without first consuming them, such as tourism and hospitality [Huete-Alcocer, 2017]. Likewise, word of mouth is considered to be the most influential source of information on intention [Huete-Alcocer, 2017] and purchase decision [Litvin, Goldsmith and Pan, 2008; Reza Jalilvand and Samiei, 2012]. 
With the advancements of new technologies, the traditional word-of-mouth phenomenon has entered the digital world. From the first definitions of the electronic mouth-ear, Hennig-Thurau et al. [2004], define the concept as:

Any positive or negative statement made by potential, actual, or former customers about a product or company, which is made available to a multitude of people and institutions via the Internet (p. 39).

Currently, the new version of the word of mouth is known as the electronic word-of-mouth or eWOM [Yang, 2017]. Due to the appearance of new online platforms, this form of communication has gained importance and therefore has made it one of the most influential sources of information on the web [Abubakar and Ilkan, 2016].

On the other hand, Litvin, Goldsmith and Pan [2008] describe eWOM as all that informal communication on the internet directed to consumers and related to the use or characteristics of goods, services or sellers. The advantage of this tool is that it is available to all consumers who can also use online platforms to share their opinions with other users [Huete-Alcocer, 2017].

The wide variety of digital tools, especially mobile devices, allow users and consumers to share information anytime, anywhere [Levy and Gvili, 2015]. As a result of these technological advances, the new media have led to changes in consumer behavior [Serra Cantallops and Salvi, 2014; Gómez-Suárez, Martínez-Ruiz and Martínez-Caraballo, 2017], due to the great influence exerted by the one about the other [Reza Jalilvand and Samiei, 2012] by sharing opinions and information about companies, products and brands [Gómez-Suárez, Martínez-Ruiz and Martínez-Caraballo, 2017]. As online content sharing becomes easier, the amount of information available to audiences has increased dramatically [Hennig-Thurau et al., 2004].

The authors Nabi and Hendriks [2003] assure that the high level of credibility of the electronic word of mouth is "the extent to which one perceives the recommendations or opinions of other consumers as credible, truthful and objective". In such a way that credibility:

- it is essential in the adoption of eWOM [McKnight and Kacmar, 2006]

- increases responsiveness [Kozinets, 1999; Fox and Roberts, 1999];

- increases purchase intentions [Nabi and Hendriks, 2003; Riegner, 2007].

The electronic word of mouth is considered to be a very reliable source of information compared to the messages generated by the brands because it is generated and disseminated among users without commercial interests [Brown, Broderick and Lee, 2007].

It is common for users to trust more consumers than providers [Nieto, Hernández-Maestro and Muñoz-Gallego, 2014]. Therefore, word of mouth can influence many recipients [Lau and $\mathrm{Ng}, 2009$ ] and is considered as a marketing 
channel dominated by consumers where the issuers are independent of the market, which generates credibility among them [Brown, Broderick and Lee, 2007]. Again, this makes the mouth-ear a credible and reliable source [Arndt, 1967; Lee and Youn, 2009].

\subsection{Influencer marketing}

Today, due to the great advances in the development of communication and technology, the internet is important both for users, who have the possibility to share their opinions, and for brands. Brand managers seek to generate interaction and engagement with online communities [Uzunoğlu and Kip, 2014].

After many decades of research in the field of social sciences, it has been shown that in any community there is always a group of people whom others admire and seek to help them form opinions on various topics [Weimann, 2016]. Known as opinion leaders or influencers, these people influence the formation of opinions, attitudes on various topics, and general knowledge [Weimann et al., 2007].

Until a decade ago, some studies considered face-to-face communication and personal interaction to be essential for opinion leadership [Uzunoğlu and Kip, 2014]. Today, due to technological developments, face-to-face communication is no longer considered as the sole determinant for personal interaction. Instead, online communities are intertwined through the internet without the need to be in the same geographic space [Boase et al., 2006].

The emergence of new digital platforms has affected the model of diffusion of innovation in science communication and thus digital influencers have emerged who can disseminate information through online communities [Uzunoğlu and Kip, 2014]. Influencer marketing is a relatively new business model (IAB Spain) where opinion leaders known as influencers are individuals who have certain knowledge and experience on a particular topic. In general, these individuals give information and advice to their "followers", therefore, they are more likely to influence purchasing decisions through word of mouth communication [Weimann et al., 2007].

The figure of the influencer or prescriber can be defined as: those leaders of digital opinion in social networks that transmit information to an unknown mass audience [Uzunoğlu and Kip, 2014; Gräve, 2017].

IAB Spain [2019] defines the figure of the influencer as:

Those people who are considered to have the potential to create engagement, drive conversation and/or influence the decision to buy products/services from a target audience. These individuals can range from celebrities to lesser-known profiles in a general scope, but recognizable in their own niche, more specialized (p. 16).

These prescribers are more likely to talk about products or services and also seek to know about the opinions of others [Solomon, 1994]. They are active and innovative communicators because they go beyond simply purchasing the products and are in 
charge of discussing the negative or positive aspects of said products [Weimann et al., 2007].

As more users adopt the use of social networks, brands are abandoning traditional advertising practices and are betting more on advertising through influencers [De Veirman, Cauberghe and Hudders, 2017]. According to the Digital Marketing Institute, $74 \%$ of users are influenced in purchasing decisions through social networks and $67 \%$ of marketing managers promote content through influencers. These digital opinion leaders have the ability to influence the attitudes, decisions and behavior of their audience through the activities they carry out on social networks [Lyons and Henderson, 2005; Watts and Dodds, 2007].

Due to the characteristics they possess, companies seek to make paid collaborations so that their brands and products are promoted in this way. These collaborations range from unique publications promoting a product or long-term contracts involving the influencer figure as a brand ambassador to "own" product lines dedicated and promoted by themselves [Lee and Watkins, 2016].

\subsection{KPIs that measure the success of an influencer on Instagram}

One of the most questioned questions among professionals in the sector is how to measure success? These consider that the reach that an influencer has and the number of interactions that they generate with their audience are the most important metrics to measure success [Gräve and Greff, 2018].

Advertisers rely on the metrics known as key performance indicators (KPIs) to choose the best influencers to work with and to measure the success of the campaigns [Peters et al., 2013].

According to IAB Spain, each advertiser makes a report with a certain periodicity that includes the KPI's that have been previously determined at the time of planning the campaign and according to the needs of the brand. In this way the advertiser can know if the defined objectives are being achieved.

IAB Spain [2019] states that there are certain metrics that are considered essential to execute successful influencer marketing campaigns. The metrics offered by Instagram to measure the effectiveness of a publication are the following:

Followers: number of people who follow the profile.

Publications: number of contents in the account.

Interactions/engagement: number of interactions with the content carried out.

Likes: number of likes that a publication gets.

Comments: number of comments on the publication.

Times saved: number of times users have saved the post.

Times shared: the number of times users have sent posts either through direct messages or shared content on Instagram stories. 
Views: the number of users who have played a video.

Reach: number of unique users who have viewed the publication. Along with this data it is also possible to see what percentage of users are reached and are not followers of the account.

Impressions: number of users who have seen the publication.

\subsection{Projection of the sector in Spain}

Since Instagram is the best showcase for influencer marketing, more and more brands are using it. In Spain, influencer marketing is a consolidated reality [Brandmaniac, 2018]. Instagram is the fastest growing social network in 2019. In mid-2018, it announced that they had reached a billion active users. Users post close to 95 million photos and videos a day, as well as 400 million daily Stories and "likes" around 4.2 billion posts [Influencer Marketing Hub, 2019].

As influencer marketing becomes more popular, there are more and more agencies specialized in this new trend every day that offer advice on how to choose the right influencers and manage the campaigns carried out on this platform [Brandmaniac, 2018; Influencer Marketing Hub, 2019].

Over the last few years it can be seen that influencer marketing has had exponential growth in the Spanish market. The reasons for the growth of this trend are several: the degree of satisfaction with the results obtained and a greater return on the investment made, the ease of measuring concrete results and the power of influence [Brandmaniac, 2018].

According to Brandmaniac [2018], the main objectives of the campaigns are the capture of new audiences and the loyalty of current audiences. It was also found that there are other goals such as launching new products on the market and increasing the size of the brand community on social networks. The same study revealed that in Spain, 56.5\% of Spanish brands leave campaign management with influencers to specialized agencies [Brandmaniac, 2018].

\subsection{Use of social networks by professionals in the pharmaceutical sector}

Over the years, the internet has been used among professionals in the pharmaceutical sector to offer services and products to consumers [Crawford, 2003; Wagner, Alonso and Mehlhorn, 2001]. Several pharmacies have websites to complement their traditional business model, and there are even some that only operate online [Crawford, 2003].

Moorhead et al. [2013] affirm that social networks can contribute to health care since they are versatile media for the public, patients and professionals in the sector, allowing scientific communication to find other transmission routes. According to Benetoli et al. [2017] pharmacists, being specialists in medicines, have a lot of knowledge to contribute about them on social networks. They have the power in their hands to find new ways to offer services to communities and individuals. 
The study by Benetoli et al. [2017] focused on investigating the use of social networks by pharmaceutical professionals. From the analysis, two themes emerged related to the use (or potential use) of social networks for patient care: social and pharmaceutical networks, and the online interactions of these professionals with the public and patients. Pharmacists, on their personal Facebook accounts, were found to sometimes post or share health-related information to educate their contacts on certain topics. Likewise, some of the participants acknowledged that, occasionally, they shared health tips for their friends and followers on Facebook and Twitter because there are certain issues that generate concerns among them [Benetoli et al., 2017].

In Spain, healthcare professionals have been adapting to new communication trends such as influencer marketing [Gonzales, 2019]. In September 2018, an online congress on pharmacy management and marketing was held where industry experts explained the importance of implementing the use of social networks in the pharmaceutical sector, expanding the channels for scientific communication in the sector.

Poch [2018] states that the great challenge that pharmacies have today is to know how digital businesses work and points out that it is very important to know the audience and establish trust-building links. It also ensures that pharmacies that do not have a presence on social networks are at a "disadvantage".

According to Sastrón [2018], all pharmacies must be digitized and specialized, but this should not be focused solely on generating online sales. He also affirms that both blogs and social networks generate a closer relationship with the patient. So far, no scientific study has been found on the use of social networks by professionals in the pharmaceutical sector in Spain.

Objectives

The general objective of this research is to understand the communication management of the six most influential pharmaceutical influencers through their social networks during the COVID-19 pandemic. The specific objectives are:

- To know which publication formats generate more interactions

- To know which themes generate more interactions

- To know which are the most treated topics

- To know if most of the observed influencers work with sponsored content

- To know if the number of followers of each prescriber increases during the observation period.

Methods

This research will carry out a qualitative methodology through the observation method; this observation was made between January 20 and March 31 2020. The analysis time coincides with the dates on which the first cases of COVID-19 were confirmed in Europe, precisely on January 24 in France [Lescure et al., 2020]. According to Ruiz Olabuénaga [2012] there are five phases within a qualitative 
investigation: definition of objective/s, work design, data collection, data analysis and investigation report.

According to Monje Álvarez [2011], the qualitative method does not consist of a fixed and unchangeable framework, but rather a point of reference where the objectives, the strategy (how it should be proceeded) and the collection are indicated, which techniques are to be used.

To carry out the general objective, firstly, key concepts within the theoretical framework have been analysed to understand the importance of the word of mouth phenomenon, opinion leaders and the influence they have on consumer purchasing decisions and perceptions. The next thing will be to observe and identify which are the KPIs that measure success.

\subsection{Sample selection}

This research focuses on the communication management of pharmaceutical influencers on Instagram during the Coronavirus crisis in Spain. For the selection of the sample, we have used intentional sampling [Abela, 2002], in which the subjects of the sample are not chosen at random, but intentionally. The selection will make use of the intentional "opinion" sampling, in which the researcher selects the informants according to personal strategic criteria: such as knowledge of the situation, ease, notoriety, etc. [Abela, 2002]

The selection of the sample has been chosen based on articles on websites that have named these pharmacists as influential figures within the field. The sample has been obtained from the different rankings of influencers mentioned in various blogs and magazines of pharmaceutical interest such as: En Genérico [2019], website promoted by the Spanish Association of Generic Medicines, Club de la Farmacia [2019], blog dedicated to Spanish pharmacists and Portalfarma, platform of the General Council of Official Colleges of Pharmacists (2019). In addition, and taking into account that most of the pharmaceutical influencers have become known in the cosmetic area, articles published in Vogue Spain (2018) and Telva (2019) were also considered.

This sample is based on the number of followers that the prescribers mentioned in the articles, for this we take as valid the data of IAB Spain [2019] that classifies as a micro influencer the profile that has between $10 \mathrm{k}$ and $50 \mathrm{k}$ followers and as a medium influencer the profile that has between $50 \mathrm{k}$ and $250 \mathrm{k}$ followers. In this case 6 specialists from the sector have been chosen who have a number of followers of more than $12 \mathrm{~K}$ and who are very active on the Instagram platform generating constant interaction with their audiences. Next, the selected profiles will be described:

@boticariagarcia. Marián García is not only a doctor in pharmacy, but also a nutritionist. She currently has a base of 224,000 followers. She is professionally dedicated to health outreach and has published a book this year called "York Ham Does Not Exist." This is a guide to healthy shopping. 
@martamasi5. Marta Masi is a pharmaceutical specialist in dermo-cosmetics and has a base of 41,200 followers on Instagram. She has a website where, apart from selling parapharmacy products, it has a blog specialized in cosmetics and skin care.

@farmacia_enfuerecida. Guillermo Martín Melgar, pharmacist and author of the book "Esta Farmacia es una Cruz" has 73,800 followers on Instagram.

@arbosana_farmacia. Beauty, cosmetics and health. Rocío Escalante has 13,700 followers. She has a website connected to a blog focused on skincare issues.

@sansi_farma. Esther Sansi is the specialist behind this profile. She has a base of 25,200 followers and deals with health and skin issues.

@Medicadoo. These two pharmacists, Pablo García and Lalo Gastalver, are two from the sector that offer advice on social networks. This profile currently has a base of 27,700 followers.

\subsection{Data collection}

According to the author Ruiz Olabuénaga [2012] there are three techniques that are used for data collection: observation, interview and content analysis. This research aims to collect information through content analysis.

Content analysis in a broad sense, which is how we are going to understand it in this work, is a technique for interpreting texts, whether they are written, recorded, painted, filmed..., or another different form where all kinds can exist: data records, transcription of interviews, speeches, observation protocols, documents, videos, ... the common denominator of all these materials is their ability to host content that read and interpreted properly opens doors to knowledge of various aspects and phenomena of social life [Abela, 2002].

For Abela [2002], the characteristic of content analysis and what distinguishes it from other sociological research techniques is that it is a technique that intrinsically combines observation and production of data, and interpretation or analysis of data.

As stated in the theoretical framework, the most relevant metrics to measure the success of an influencer on Instagram are the number of likes and the percentage of engagement they generate in relation to the base of followers they have.

In this case, we will analyse what type of content is published (subject of the publications), what type of format the publications are in (video or image), how much engagement the publications generate in terms of "likes" and comments", and which is the theme that generates the most interaction. As a complement to the observation, we will see if the number of followers increases and see if the content they publish is sponsored. 


\subsection{Evaluation criteria and description of the variables}

Topic: this variable focuses on categorizing the type of topics that each publication deals with. Within this variable are different categories:

Health: this category covers all topics related to health, diseases, vaccines, medications, prevention measures, among others.

Beauty: this category covers everything from skin care, makeup, beauty treatments, cleansing and exfoliation routines and hair care.

Personal: this category defines those publications that are personal in nature such as "selfies", personal images and/or the prescriber's personal life.

Coronavirus: this category includes all publications dealing with the subject of the pandemic. Infographics, prevention measures, medication, symptoms and general information.

Product/promotion recommendation: this category includes all those publications that recommend products, promote events, workshops, campaigns or books.

Humor: this category defines any publication that has humor content.

Nutrition: this category classifies all publications that deal with food and nutrition topics.

Others: all those publications that cannot be classified as health, beauty, personal, humor, coronavirus or nutrition.

Format: this variable will determine what format the publications are in: Image, video or image and video.

Engagement: this variable analyses which publications generate the most interaction according to the number of "likes" and comments.

Post sponsored: this variable will determine if the posts with ads/advertisements are sponsored by the brands.

Audience size: this variable determines the initial number of followers of each prescriber in a given observation time and the number of followers at the end of the investigation period to determine whether the number of followers has increased in the selected period of time.

Table 1. Observation criteria. Source: own elaboration.

\begin{tabular}{|c|c|}
\hline Topic & $\begin{array}{c}\text { Health, Beauty, Nutrition, Personal, Product recommendation/ } \\
\text { promotion, Coronavirus, Humor, Others }\end{array}$ \\
\hline Format & Image, video, video and image \\
\hline Engagement & Number of likes and comments \\
\hline $\begin{array}{c}\text { Does it indicate that it } \\
\text { is a sponsored post? }\end{array}$ & Use of hashtags: \#ad \#advertising \\
\hline Audience size & Number of followers \\
\hline
\end{tabular}


After the methodology used, which is based on analysing a total of 394 posts published starting from January 20 to March 312020 by the six influencers described, the results of each selected influencer are detailed individually and then the general results are analysed.

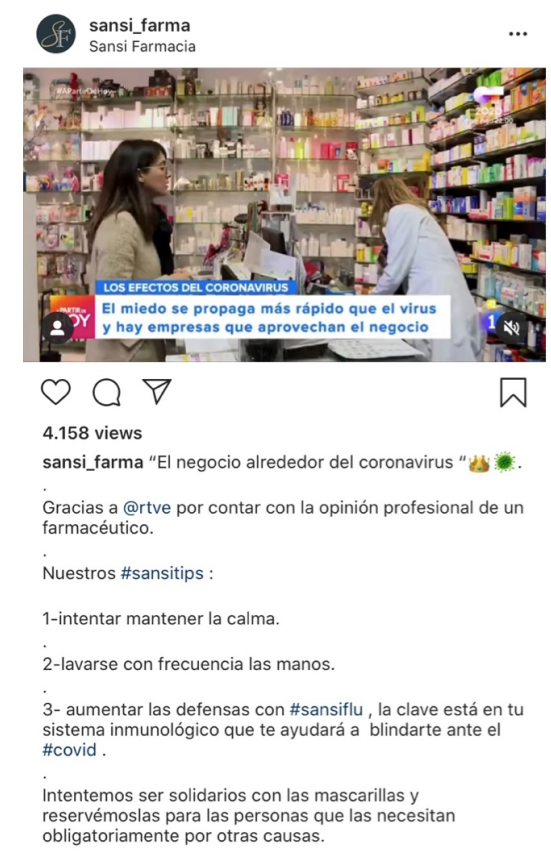

Figure 1. Video with more views. Source: Instagram, 4th March 2020.

@Sansi_farma. This influencer has made a total of 57 publications, 3 in video format and 54 in image format. Within the analysed sample, it has been found that the most used topic has been "product recommendation and/or promotions" with $30 \%$ followed by the "others" category with $25 \%$, "beauty" with $16 \%$, "health" with $12 \%$, "nutrition" with $12 \%$, "Coronavirus" with $3 \%$, and "personal" with $2 \%$. No publication was identified under the category of "humour".

From the results obtained from the selection of the sample, it should be noted that, in no case has it been possible to identify whether the publications that recommend or promote a product have been sponsored.

Out of a total of 17 products that fall under the category of "product/promotion recommendation" 4 are food supplements, 11 are personal care/hygiene products and 2 are bracelets that support different causes.

Within the "others" category, several publications have been identified naming special days such as Valentine's Day, cancer-fighting day, women's day, among others. It has also been possible to identify, within the category "others", publications showing articles published in magazines written by it.

Among the topics that have generated the most interaction in terms of "likes" is a publication categorized as "personal" since it is a personal image of the same influencer. This image is the one with the highest number of "likes", accumulating a total of 1,227 "likes". 
The video with the most views (Figure 1) is categorized under the "Coronavirus" topic and has a total of 4,158 views. The publication that has generated the most comments is an image that is categorized as "product/promotion recommendation" and has a total of 18 comments.

In early March, this prescriber had a follower base of 25,100 and at the end of the observation period on March 31, 2020, the follower base increased to 25,200. There was an increase of 100 new followers.

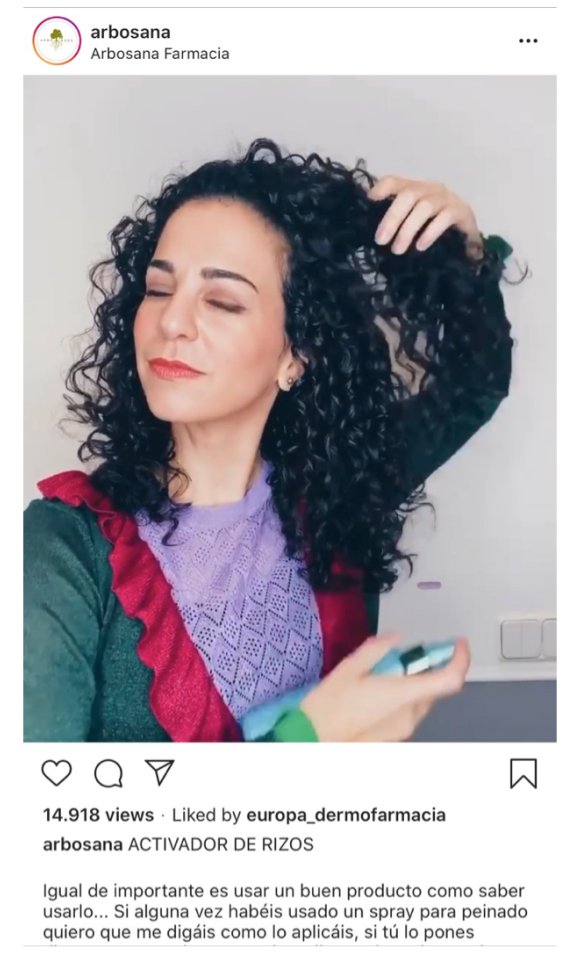

Figure 2. Video with more views. Source: Instagram, 6th March 2020.

@Arbosana. Within the observation period, this prescriber has published 38 posts, 7 in video format and 31 in image format. It has been observed that the most used topic has been "product/promotion recommendation" with $42 \%$ followed by the "personal" category with $24 \%$, "beauty" with $16 \%$, "others" with $13 \%$ and "health" with $5 \%$. No posts were found under the "Coronavirus", "nutrition" or "humor" categories.

In the "product recommendation/promotion" category, it was not possible to identify whether these publications have been sponsored or not and the type of recommended products are products for skin or hair care only.

The second category with a total of 9 publications has been "personal" which includes images of the personal life of this prescriber.

The publication that has generated most likes has been, once again, a "personal" image of the prescriber with a total of 1806 "likes". The video with most views has 14,918 and recommend the use of a hair product (Figure 2). The publication that has generated most comments is the same "personal" publication that accumulates 1831 "likes" and a total of 304 comments. 
In early March, this prescriber had a follower base of 13,500 and at the end of the observation period on March 31, 2020, 13,700 followers were registered. There was an increase of 200 new followers.

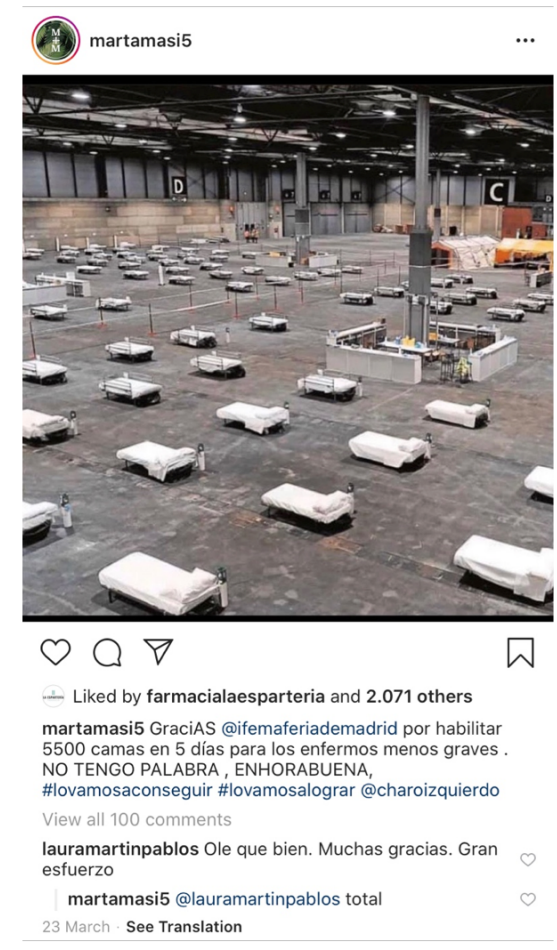

Figure 3. Image with more "likes". Source: Instagram, 23rd March 2020.

@Martamasi5. This prescriber has made a total of 28 publications, 5 in video format and 23 in image format. The topic most used in their publications is "product recommendation/promotion" with 36\% followed by the category of "others" with $32 \%$, "beauty" with $25 \%$, "Coronavirus" with $4 \%$ and "health" with $3 \%$. Lastly, there is no publication dealing with nutrition, humour or personal.

The products that appear in the publications that are under the category of "product recommendation/promotion" are, for the most part, personal care and in no case could it be identified that they are sponsored content.

Posts that are categorized under "others" include images that cover different topics and that could not be specifically identified within the previously described categories.

The publication that has generated most "likes" has been an image where Ifema Madrid is thanked for enabling 5,500 beds for patients with Coronavirus, which accumulates a total of 2,071 "likes" (Figure 3). The publication that obtained the most comments is an image showing the donation boxes for Ifema Madrid that the pharmacy made. The publication accumulates a total of 363 comments and, finally, the video that accumulates the most views, 4,972, is about an event carried out by the pharmacy. 
At the beginning of March, this prescriber had a follower base of 40,700 and at the end of the observation period on March 31, 2020, 41,200 followers were registered. There was an increase of 500 new followers.

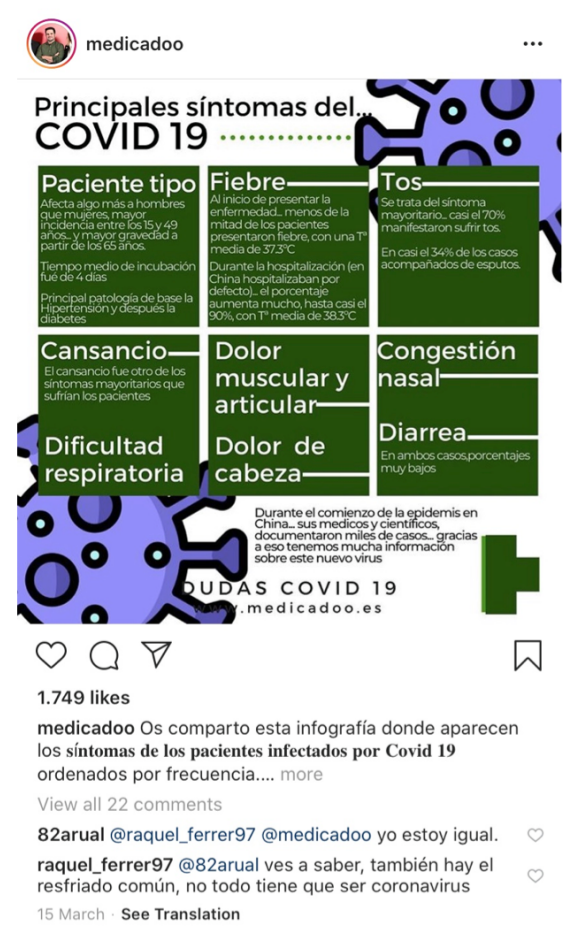

Figure 4. Publication example. Source: Instagram, 15th March 2020.

@Medicadoo. This prescriber has made a total of 43 publications only in image format. Within the analysed sample, it has been found that the most used topic in their publications has been about "Coronavirus" with $40 \%$, followed by "health" with 30\%, "product/promotion recommendation" and "beauty" with $9 \%$, "Nutrition" and "others" with 5\%, and finally "humour" with $2 \%$. No posts categorized as "personal" were found.

All publications on "Coronavirus" have been informative infographics on symptoms, general virus information, and prevention measures. "Health" publications are also infographics about some diseases, vaccines, and some medications (Figure 4).

As for the publication that has the most "likes", it is a personal image that in the description "claims" how the role of the pharmacist has been underestimated by the director of the Center for Coordination of Emergencies and Health Alerts during the Coronavirus crisis. This post has a total of 2674 likes and a total of 288 comments. The publication with the most comments is an image that deals with the subject of vaccination in pharmacies. It has a total of 585 comments and 1,038 "I like you".

At the beginning of March with 26,400 and as of March 31, 2020 a total of 27,700. That is, throughout the month of March there was an increase of 1,300 followers. 


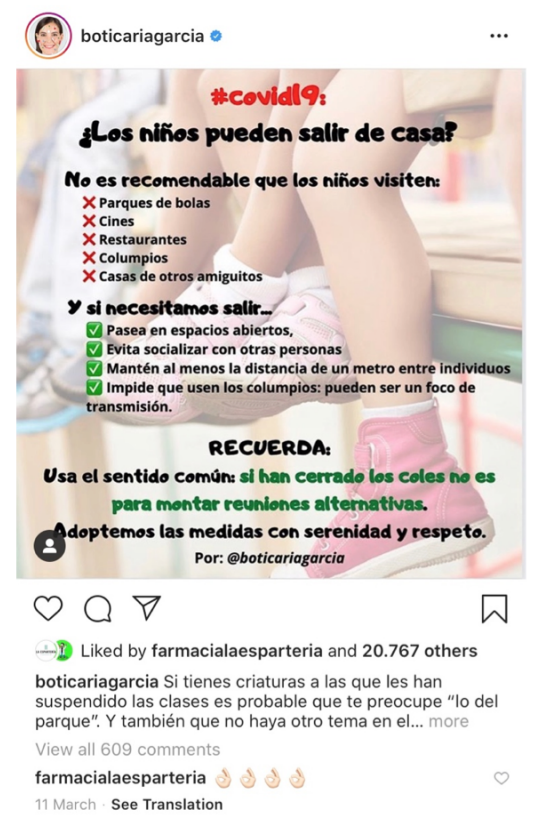

Figure 5. Example of publication. Source: Instagram, 17th March 2020.

@Boticariagarcia. Of 99 analysed publications of the sample, 74 images and 25 videos, the category with the highest percent "nutrition" with $6 \%$. No posts found under the category of "beauty" or "humour".

Of 99 publications analysed as a sample, 47 have been categorized under the theme of "Coronavirus". The posts have been observed to be informative infographics, general information about the virus, tips and preventive measures to prevent the spread (Figure 5).

The category that is in second place below "Coronavirus" with a total of 15 publications, belongs to the category of "product/promotion recommendation". In this case, the prescriber has made publications promoting her book, workshops, and the television show Zapeando where she usually appears as a guest.

Something interesting that has been observed is that, between March 10 and 31, 38 posts have been published on "Coronavirus". This date coincides with the start of the health crisis in Spain.

The publication with the most views and comments is a video in which the prescriber appears singing a song with the modified lyrics talking about the coronavirus, encouraging people to stay home and avoid going out. This post has a total of 159,482 views and 1,350 comments.

Regarding the publication that has the most "likes", it has been found that it is an informative infographic about the recommendations for children to leave home. This post was published on March 11 and at that time it had not yet been announced that Spain would enter confinement.

At the beginning of March, this prescriber had a follower base of 191,000 followers and at the end of the observation period on March 31, 2020, she had a total of 224,000 followers. His fan base has grown to 33,000 . 

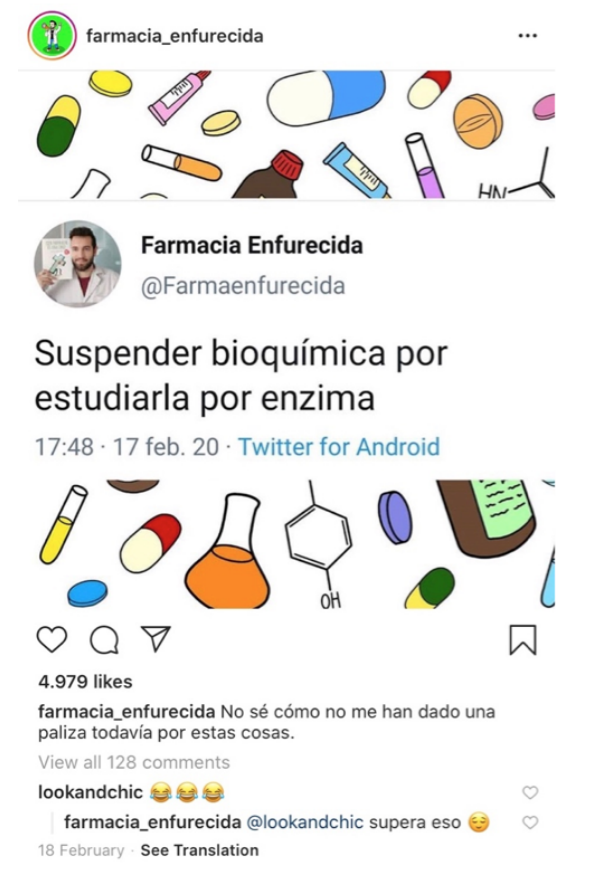

Figure 6. Example of publication. Source: Instagram, 18th February 2020.

@farmacia_enfurecida. Of the sample obtained from this prescriber, a total of 129 publications have been analysed during the observation period, 121 being in image format and 8 in video format. The category with the highest percentage is "humor" with $51 \%$, followed by "Coronavirus" with $22 \%$, "health" with $11 \%$, "others" $9 \%$, "product/promotion recommendation" $6 \%$, and finally the category "Personal" with $1 \%$. It has not been possible to identify any post under the categories of "nutrition" or "beauty".

Something very curious in this case is that 65 of 129 publications have been humorous content. Something that has drawn attention is that this prescriber makes the publications on the social network of Twitter and then uploads the image of a screenshot of the tweet to Instagram (Figure 6).

Another interesting observation is that when analysing the publications categorized as "humor", it can be inferred that the vast majority are for a public that has knowledge or is part of the pharmaceutical sector. Here is an example:

The second category with the most number of publications is about "Coronavirus" with a total of 28 publications in total where it deals with the current situation of pharmacies during the COVID-19 crisis, advice to patients, and recommendations to prevent the spread of the virus.

The publication that has generated the most interaction in terms of the number of "likes" is an image with a total of 10,491, which is about reducing activity and avoiding bars. This publication was made on March 12, two days before the Government declared confinement in Spain.

The video with the most views has a total of 53,508 views and 170 comments is about the current situation of pharmacies and additional preventive measures 
during the Coronavirus crisis. This video highlights what are the necessary measures to avoid contagion within the pharmacy, such as the importance of keeping distance between the pharmacist and the patient when making the purchase. The publication that has generated the most comments is an image that shows a screenshot of a news item in which the Government announces that pharmacists will not be protected during the coronavirus crisis. This post has 932 comments and 7602 likes.

The base of followers of this prescriber at the beginning of March was 68,000. As of March 31, 2020, an increase of 5,800 new followers was seen, making a total of 73,800 .

\subsection{General results}

Of the 394 posts analysed that were published during January 20 to March 312020 by the six influencers, 95 (24\%) have been about COVID-19 followed by "product/promotion recommendation" with 69 publications, 66 of "humour", 53 of "others", 51 of "health", 26 of "beauty", 19 of "personal" and finally only 15 publications of "nutrition", the criteria analysed are mutually exclusive, that is, one category automatically excludes another (Table 2 and Figure 7). These results clearly show that the topic most dealt with during the period of time analysed has been about the Coronavirus pandemic.

Table 2. Summary of total frequency of publications depending on the subject. Source: own elaboration.

\begin{tabular}{|c|c|c|c|c|c|c|c|}
\hline Topic & $\begin{array}{c}\text { Sansi } \\
\text { Farma } \\
(57)\end{array}$ & $\begin{array}{l}\text { Arbosana } \\
\quad(38)\end{array}$ & $\begin{array}{c}\text { Marta } \\
\text { masi (28) }\end{array}$ & $\begin{array}{l}\text { Medicadoo } \\
\quad(43)\end{array}$ & $\begin{array}{c}\text { Boticaria } \\
\text { García } \\
(99)\end{array}$ & $\begin{array}{c}\text { Farmacia } \\
\text { Enfurecida } \\
\text { (129) }\end{array}$ & $\begin{array}{l}\text { Total } \\
(394)\end{array}$ \\
\hline Health & 7 & 2 & 1 & 13 & 13 & 15 & 51 \\
\hline $\begin{array}{c}\text { Product Recommendation/ } \\
\text { Promotion }\end{array}$ & 17 & 16 & 10 & 4 & 15 & 7 & 69 \\
\hline Coronavirus & 2 & 0 & 1 & 17 & 47 & 28 & 95 \\
\hline Beauty & 9 & 6 & 7 & 4 & 0 & 0 & 26 \\
\hline Personal & 1 & 9 & 0 & 0 & 7 & 2 & 19 \\
\hline Others & 14 & 5 & 9 & 2 & 11 & 12 & 53 \\
\hline Humor & 0 & 0 & 0 & 1 & 0 & 65 & 66 \\
\hline Nutrition & 7 & 0 & 0 & 2 & 6 & 0 & 15 \\
\hline
\end{tabular}

As can be seen in the chart (Figure 8), the prescriber who increased the most followers was @Boticariagarcía with 33,000, followed by @farmacia_enfurecida with 5,800, @medicadoo with 1,300, @farma_martamasi with 500, @arbosana with 200, and finally @sansi_farma with 100.

As @Boticariagarcía is the prescriber who published the most about COVID-19 during the health crisis in Spain, it can be inferred that the great increase in followers is due to the fact that she is constantly publishing information of interest about the pandemic and that probably many followers seek information through the content she shares.

In the chart of Figure 9, it can be seen that, of 394 analyzed posts, 48 are in video format and 346 in image format. 


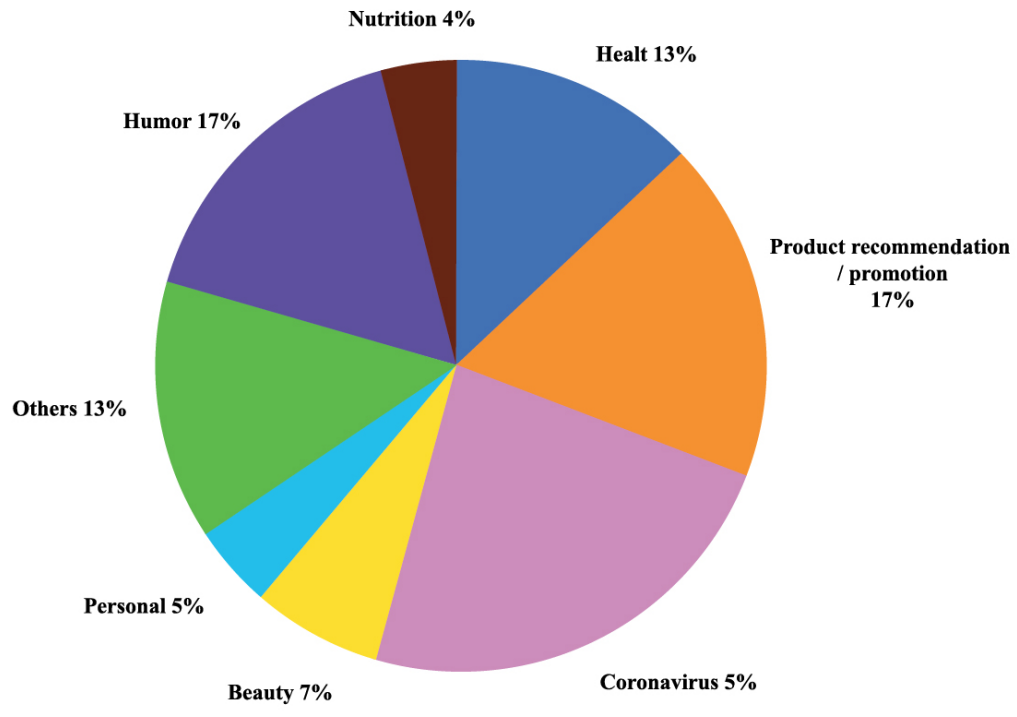

Figure 7. Percentage data of the "thematic" variable. Source: own elaboration.

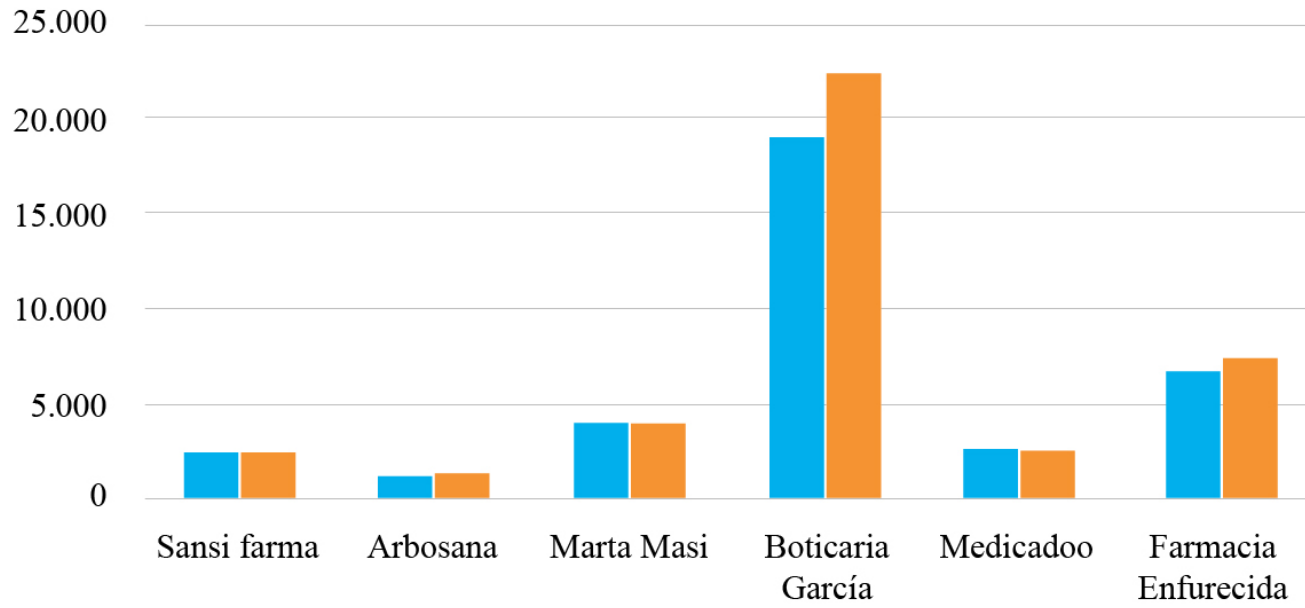

= $05 / 03 / 2020 \quad=31 / 03 / 2020$

Figure 8. Increase in followers in March. Source: own elaboration.

To determine which publications generated the most interaction from each influencer, they were selected based on:

- What was the publication in image format that obtained the most likes?

- Which was the publication in video format with the most views?

- Which publication had the most comments? 


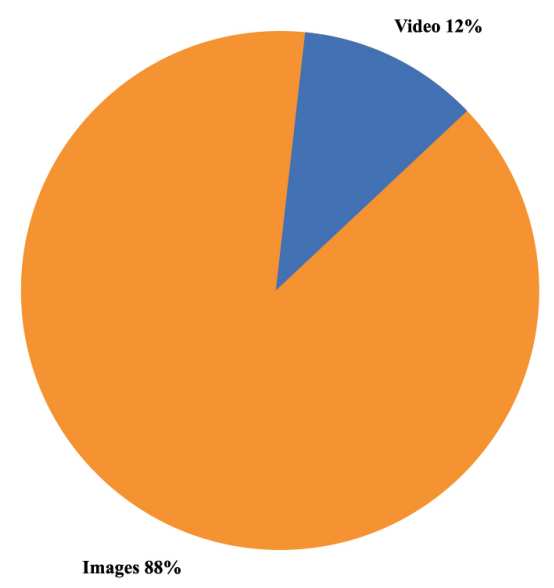

Figure 9. Percentage data of the format variable. Source: own elaboration.

Of 17 publications in both formats, 11 of 17 are in image format and 6 of 17 in video format. The publications in image format that generated the most interaction according to the number of "likes" and the number of comments, 4 of 11 publications were about Coronavirus and of the publications in video format, 4 of 6 were about Coronavirus. Of all the publications that obtained the most "likes" and views, 8 out of 17 were about the COVID-19, therefore, it can be concluded that the theme that generated the most engagement was "Coronavirus". The two charts showing the overall percentages of posts in image and video format can be found in Figure 10 and 11 respectively.

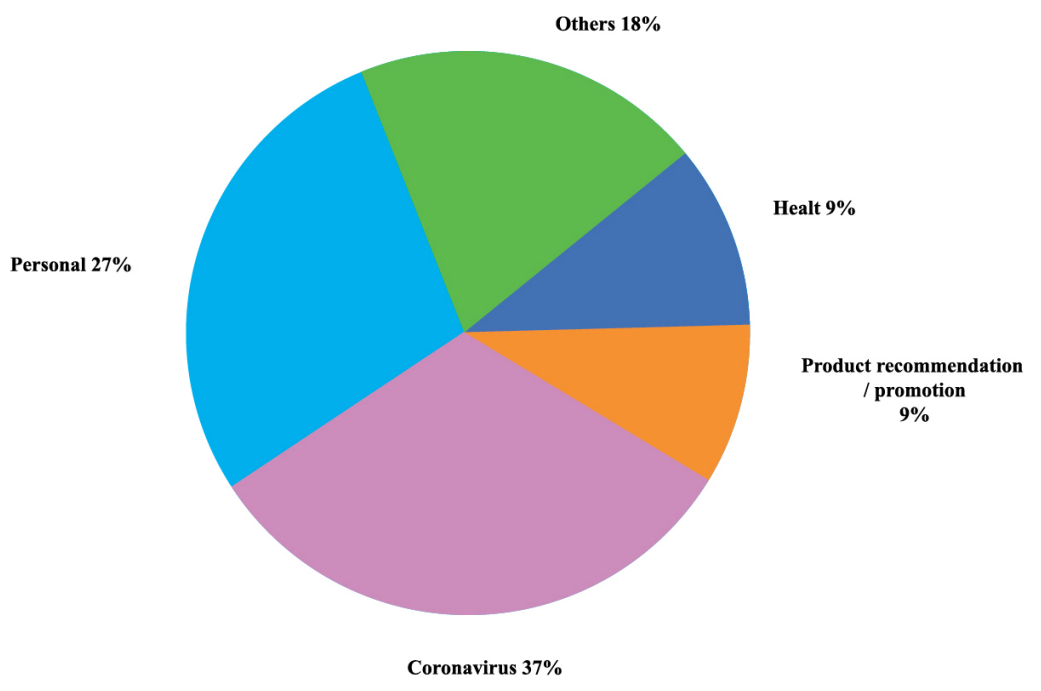

Figure 10. Percentage data for the Image category. Source: own elaboration.

Regarding the publications that received the most comments, it can be seen that 4 of 6 deal with the COVID-19 crisis. Something interesting is that 


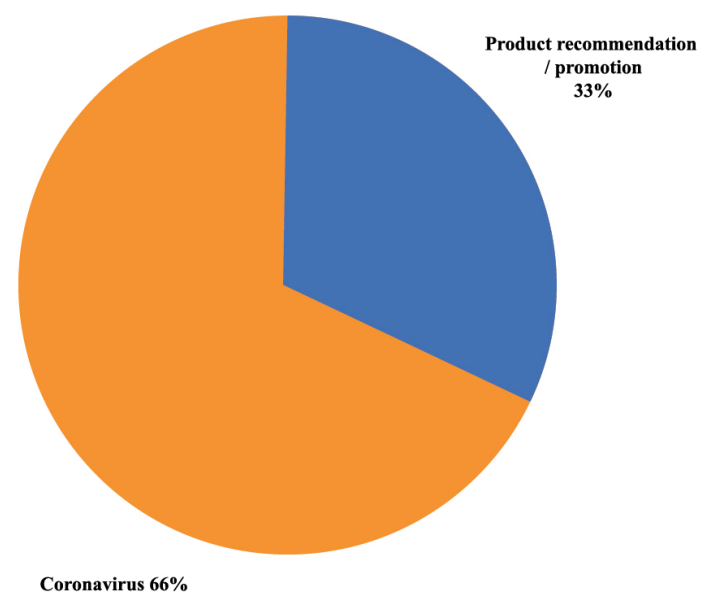

Figure 11. Percentage data for the Video category. Source: own elaboration.

@farmacia_enfurecida and @medicadoo made two posts on the same topic and found that they were the ones with the most comments. These two publications are in image format and deal with the statement made by the director of the Center for Coordination of Emergencies and Health Alerts where he states that no protective equipment will be provided for pharmaceutical officials during the health crisis.

Discussion and conclusions
The results obtained in this research allow us to know the communication management of pharmaceutical influencers through Instagram during the COVID-19 pandemic in Spain. In accordance with the specific objectives previously described, it can be concluded that:

- The publication formats that generated the most interaction were both videos and images. During the observation period, more images than videos were published, but it cannot be specifically said which format generated more interaction.

- It can be concluded that the topic that generated the most interaction was about the COVID-19 pandemic.

- In no case could it be identified if the observed influencers work with sponsored content since no publication under the category of "product recommendation/promotion" had the hashtags \#ad or \#advertising.

- It can be affirmed that all the analysed prescribers have increased their base of followers during the observed period.

Over the years, it has been shown that in any community there is always a group of people with specific knowledge in a field, who help other people to form opinions on various topics [Weimann, 2016]. Pharmacists on Instagram disseminate content based on industry knowledge and experience and are therefore considered opinion 
leaders. The content shared by these industry experts generates credibility that influences the formation of attitudes to various health, nutrition and personal care issues.

The topic on which more publications were made and also the one that generated the most interaction was on the Coronavirus. Informative infographics and explanatory content that seeks to inform the population about different aspects related to the virus are very useful in raising public awareness of the seriousness of the situation.

It has been found that the profiles of @boticariagarcia, @farmacia_enfurecida and @medicadoo have shared informative content on health issues, especially on the COVID-19. These prescribers have not only reported on the symptoms and risks caused by COVID-19, but they have also made publications encouraging people to stay home and comply with confinement regulations to prevent further spread of the virus.

As Moorhead et al. [2013] affirm in their study, social networks can bring a new dimension to health care. Taking this statement into account, it can be inferred that all the information shared about COVID-19 has been disseminated for the purpose of informing and educating the population about the risks of COVID-19 and the prevention and precautionary measures that must be taken to avoid the spread and spread of the virus.

Regarding the general analysis of the communication management of pharmaceutical influencers, it has been found that 3 of the 6 observed profiles share and create content focused on dermo-cosmetics. Prescribers' @sansi_farma, @martamasi5 and @arbosana made more publications recommending products that were mostly products for personal care, skin care and hair care. It should be emphasized that, in none of these cases, it was possible to identify if it is sponsored content.

Another relevant observation is that @farmacia_enfurecida's profile has been found to create and share humorous content that is largely aimed at an audience with knowledge of the pharmaceutical sector.

Regarding the number of followers that each prescriber has gained during the observation time, it can be concluded that the prescribers who are mainly engaged in dermo-cosmetics did not increase the number of followers much compared to the prescribers who did publish more content on COVID-19. This may be because people today need to be informed about issues related to the Coronavirus pandemic and are therefore seeking to obtain that information from reliable sources.

As Benetoli et al. [2017] establish in their research, it is concluded that the pharmacists observed in this research publish and share information related to health and dermo-cosmetic issues that seek to educate their contacts or followers on certain issues that many times they generate concerns.

Finally, it is concluded that not all the influencers observed, during the period of the current health crisis, have focused mainly on generating content related to 
COVID-19. It can be inferred that this is due to the fact that there are certain profiles that are specialized and more focused on dermo-cosmetics and that there are other profiles that have an informative role more focused on treating health issues in general.

Limitations of the study and future lines of research
One of the main limitations of this research was the period of time to carry out the observation of the publications. The observation time was limited by the delivery period of the call for publication of articles.

Another limitation of this study is with respect to the selected sample. The selection criteria were based on those prescribers who were mentioned in three articles as influential figures within the sector and who had a minimum base of 12,000 followers.

In this study, communication management has only been analysed through the posts that have been published on Instagram. The limitation regarding this aspect is that the Instagram "Stories", content that is shared on the network and that is visible for 24 hours, have not been analysed. As this is a widely used tool within Instagram, the content that these influencers share in the "Stories" may be different from the content that is published in the profile. Therefore, the results of this study are subject to the interpretation of the results obtained only based on the analysis of the publications on Instagram.

Future research may be carried out with a larger sample selection, within a longer period of time and including other social media.

Abela, J. (2002). Las técnicas de análisis de contenido: una revisión actualizada. Sevilla, Spain: Fundación Centro de Estudios Andaluces.

Abubakar, M. and Ilkan, M. (2016). 'Impact of online WOM on destination trust and intention to travel: a medical tourism perspective'. Journal of Destination Marketing $\mathcal{E}$ Management 5 (3), pp. 192-201. https://doi.org/10.1016/j.jdmm.2015.12.005.

Arndt, J. (1967). Word of mouth advertising: a review of the literature. U.K.: Advertising Research Foundation.

Bampo, M., Ewing, M. T., Mather, D. R., Stewart, D. and Wallace, M. (2008). 'The effects of the social structure of digital networks on viral marketing performance'. Information Systems Research 19 (3), pp. 273-290. https://doi.org/10.1287/isre.1070.0152.

Benetoli, A., Chen, T. F., Schaefer, M., Chaar, B. and Aslani, P. (2017). ‘Do pharmacists use social media for patient care?' International Journal of Clinical Pharmacy 39 (2), pp. 364-372. https : //doi .org/10.1007/s11096-017-0444-4.

Boase, J., Horrigan, J., Wellman, B. and Rainie, L. (2006). The strength of Internet ties. Washington, DC, U.S.A.: Pew Internet \& American Life Project. URL: https://www . pewresearch . org/internet/2006/01/25/the-strength-of -internet-ties/.

Brandmaniac (2018). Estudio sobre marketing de influencers en España 2018. URL: https://www.brandmanic.com/wp-content/uploads/Estudio_Marketing _de_Influencers_en_Espa\%C3\%B1a_2018.pdf. 
Brown, J., Broderick, A. J. and Lee, N. (2007). ‘Word of mouth communication within online communities: conceptualizing the online social network'. Journal of Interactive Marketing 21 (3), pp. 2-20. https://doi.org/10.1002/dir. 20082.

Club de la Farmacia (30th October 2019). Farmacéuticos influencers: ¿Cómo ha ayudado el mundo digital a su carrera profesional? URL: https: //www. clubdelafarmacia.co m/para-estar-al-dia/el-blog-del-club/farmaceuticos-influencers/.

Crawford, S. Y. (2003). 'Internet pharmacy: issues of access, quality, costs and regulation'. Journal of Medical Systems 27 (1), pp. 57-65.

https://doi.org/10.1023/A:1021009212905.

Daugherty, T. and Hoffman, E. (2014). 'eWOM and the importance of capturing consumer attention within social media'. Journal of Marketing Communications 20 (1-2), pp. 82-102. https://doi.org/10.1080/13527266.2013.797764.

De Veirman, M., Cauberghe, V. and Hudders, L. (2017). 'Marketing through Instagram influencers: the impact of number of followers and product divergence on brand attitude'. International Journal of Advertising 36 (5), pp. 798-828. https://doi.org/10.1080/02650487.2017.1348035.

Dellarocas, C. (2003). 'The digitization of word of mouth: promise and challenges of online feedback mechanisms'. Management Science 49 (10), pp. 1407-1424. https://doi.org/10.1287/mnsc.49.10.1407.17308.

En Genérico (10th October 2019). Farmacéutico influencer: profesional de farmacia que es tendencia en redes. URL: https://www .engenerico.com/farmaceuticos-influen cers-profesionales-farmacia-tendencia-redes/.

Engel, J. E., Blackwell, R. D. and Kegerreis, R. (1969). 'How information is used to adopt an innovation'. Journal of Advertising Research 9, pp. 3-8.

Feick, L. F. and Price, L. L. (1987). 'The market maven: a diffuser of marketplace information'. Journal of Marketing 51 (1), p. 83. https://doi.org/10.2307/1251146.

Fox, N. and Roberts, C. (1999). 'GPs in cyberspace: the sociology of a 'virtual community". The Sociological Review 47 (4), pp. 643-671. https://doi.org/10.1111/1467-954x.00190.

Gladwell, M. (1994). The tipping point - how little things can make a big difference. New York, NY, U.S.A.: Abacus.

Goldsmith, R. E. and Clark, R. A. (2008). 'An analysis of factors affecting fashion opinion leadership and fashion opinion seeking'. Journal of Fashion Marketing and Management: An International Journal 12 (3), pp. 308-322. https://doi.org/10.1108/13612020810889272.

Gómez-Suárez, M., Martínez-Ruiz, M. P. and Martínez-Caraballo, N. (2017). 'Consumer-brand relationships under the marketing 3.0 paradigm: a literature review'. Frontiers in Psychology 08. https://doi.org/10.3389/fpsyg. 2017.00252.

Gonzales, R. (2019). Marketing de influencia en el sector salud: la figura del influencer. URL: https://www . aeapsalud.es/diariofarma/marketing-de-influencia-en -el-sector-salud-la-figura-del-influencer.

Gräve, J.-F. (2017). ‘Exploring the perception of influencers vs. traditional celebrities: are social media stars a new type of endorser?' In: Proceedings of the $8^{\text {th }}$ International Conference on Social Media \& Society - \#SMSociety17. ACM Press, pp. 1-5. https://doi.org/10.1145/3097286.3097322.

Gräve, J.-F. and Greff, A. (2018). 'Good KPI, good influencer?' In: Proceedings of the $9^{\text {th }}$ International Conference on Social Media and Society, pp. 291-295. https://doi.org/10.1145/3217804.3217931. 
Harrison-Walker, L. J. (2001). 'The measurement of word-of-mouth communication and an investigation of service quality and customer commitment as potential antecedents'. Journal of Service Research 4 (1), pp. 60-75.

https://doi.org/10.1177/109467050141006.

Hennig-Thurau, T., Gwinner, K. P., Walsh, G. and Gremler, D. D. (2004). 'Electronic word-of-mouth via consumer-opinion platforms: what motivates consumers to articulate themselves on the Internet?' Journal of Interactive Marketing 18 (1), pp. 38-52. https://doi.org/10.1002/dir.10073.

Huete-Alcocer, N. (2017). 'A literature review of word of mouth and electronic word of mouth: implications for consumer behavior'. Frontiers in Psychology 8. https://doi.org/10.3389/fpsyg.2017.01256.

IAB Spain (2019). Libro blanco de influencers 2019. URL: https: //iabspain. es/estud io/libro-blanco-de-marketing-de-influencers/.

Influencer Marketing Hub (2019). The state of influencer marketing 2019: benchmark report. URL: https://influencermarketinghub.com/influencer-marketing-20 19-benchmark-report/.

Katz, E. and Lazarsfeld, P. F. (1955). Personal influence: the part played by people in the flow of mass communications. Free Press.

Keller, E. (2007). 'Unleashing the power of word of mouth: creating brand advocacy to drive growth'. Journal of Advertising Research 47 (4), pp. 448-452. https://doi.org/10.2501/s0021849907070468.

Kozinets, R. V. (1999). 'E-tribalized marketing?: the strategic implications of virtual communities of consumption'. European Management Journal 17 (3), pp. 252-264. https://doi.org/10.1016/s0263-2373(99)00004-3.

Lau, G. T. and Ng, S. (2009). 'Individual and situational factors influencing negative word-of-mouth behaviour'. Canadian Journal of Administrative Sciences / Revue Canadienne des Sciences de l'Administration 18 (3), pp. 163-178. https://doi.org/10.1111/j.1936-4490.2001.tb00253.x.

Lee, J. E. and Watkins, B. (2016). 'YouTube vloggers' influence on consumer luxury brand perceptions and intentions'. Journal of Business Research 69 (12), pp. 5753-5760. https://doi.org/10.1016/j. jbusres.2016.04.171.

Lee, M. and Youn, S. (2009). 'Electronic word of mouth (eWOM): how eWOM platforms influence consumer product judgement'. International Journal of Advertising 28 (3), pp. 473-499. https: //doi.org/10.2501/s0265048709200709.

Lescure, F.-X., Bouadma, L., Nguyen, D., Parisey, M., Wicky, P.-H., Behillil, S., Gaymard, A., Bouscambert-Duchamp, M., Donati, F., Hingrat, Q. L., Enouf, V., Houhou-Fidouh, N., Valette, M., Mailles, A., Lucet, J.-C., Mentre, F., Duval, X., Descamps, D., Malvy, D., Timsit, J.-F., Lina, B., van-der-Werf, S. and Yazdanpanah, Y. (2020). 'Clinical and virological data of the first cases of Covid-19 in Europe: a case series'. The Lancet Infectious Diseases 20 (6), pp. 697-706. https://doi .org/10.1016/s1473-3099(20)30200-0.

Levy, S. and Gvili, Y. (2015). 'How credible is e-word of mouth across digital-marketing channels?' Journal of Advertising Research 55 (1), pp. 95-109. https://doi.org/10.2501/jar-55-1-095-109.

Litvin, S. W., Goldsmith, R. E. and Pan, B. (2008). 'Electronic word-of-mouth in hospitality and tourism management'. Tourism Management 29 (3), pp. 458-468. https://doi.org/10.1016/j.tourman.2007.05.011.

Lyons, B. and Henderson, K. (2005). 'Opinion leadership in a computer-mediated environment'. Journal of Consumer Behaviour 4 (5), pp. 319-329. https://doi.org/10.1002/cb.22.

Marhuenda García, C. M. (2016). ‘La influencia del word of mouth electrónico sobre las ventas de un refresco'. Ph.D. thesis. Madrid, Spain: Universidad Complutense. URL: https://eprints.ucm.es/40633/. 
McKnight, H. and Kacmar, C. (2006). 'Factors of information credibility for an internet advice site'. In: Proceedings of the $39^{\text {th }}$ Annual Hawaii International Conference on System Sciences (HICSS'06). IEEE. https://doi.org/10.1109/hicss.2006.181.

Monje Álvarez, C. A. (2011). Metodología de la investigación cualitativa y cuantitativa. Neiva, Colombia: Universidad Surcolombiana.

Moorhead, S. A., Hazlett, D. E., Harrison, L., Carroll, J. K., Irwin, A. and Hoving, C. (2013). 'A new dimension of health care: systematic review of the uses, benefits and limitations of social media for health communication'. Journal of Medical Internet Research 15 (4), e85. https://doi.org/10.2196/jmir. 1933.

Nabi, R. L. and Hendriks, A. (2003). 'The Persuasive Effect of Host and Audience Reaction Shots in Television Talk Shows'. Journal of Communication 53 (3), pp. 527-543. https://doi.org/10.1111/j.1460-2466.2003.tb02606.x.

Nieto, J., Hernández-Maestro, R. M. and Muñoz-Gallego, P. A. (2014). 'Marketing decisions, customer reviews and business performance: the use of the Toprural website by Spanish rural lodging establishments'. Tourism Management 45, pp. 115-123. https://doi .org/10.1016/j. tourman.2014.03.009.

Peters, K., Chen, Y., Kaplan, A. M., Ognibeni, B. and Pauwels, K. (2013). 'Social media metrics - a framework and guidelines for managing social media'. Journal of Interactive Marketing 27 (4), pp. 281-298. https://doi.org/10.1016/j.intmar.2013.09.007.

Poch, E. (2018). 'RRSS en la farmacia: ¿hacerlo yo, implicar al equipo o externalizar el servicio?' Farmaknowmada.

URL: https://www . farmaknowmada.com/redes-sociales-farmacia/.

Reza Jalilvand, M. and Samiei, N. (2012). 'The effect of electronic word of mouth on brand image and purchase intention: an empirical study in the automobile industry in Iran'. Marketing Intelligence E Planning 30 (4), pp. 460-476. https://doi.org/10.1108/02634501211231946.

Riegner, C. (2007). 'Word of mouth on the web: the impact of web 2.0 on consumer purchase decisions'. Journal of Advertising Research 47 (4), pp. 436-447. https://doi.org/10.2501/s0021849907070456.

Ruiz Olabuénaga, J. I. (2012). Metodología de la investigación cualitativa. Bilbao, Spain: Universidad de Deusto.

Sastrón, P. (2018). ‘Cómo conseguir ingresos on line como community manager de farmacia'. Farmaknowmada. URL: https: //www . farmaknowmada. com/entrevista - community-manager-farmacia/.

Serra Cantallops, A. and Salvi, F. (2014). 'New consumer behavior: a review of research on eWOM and hotels'. International Journal of Hospitality Management 36, pp. 41-51. https://doi.org/10.1016/j.ijhm.2013.08.007.

Solomon, M. R. (1994). Consumer behavior: buying, having and being. London, U.K.: Allyn and Bacon.

Uzunoğlu, E. and Kip, S. M. (2014). 'Brand communication through digital influencers: Leveraging blogger engagement'. International Journal of Information Management 34 (5), pp. 592-602. https://doi.org/10.1016/j.ijinfomgt.2014.04.007.

Villanueva, J. and Armelini, G. (20th December 2007). El boca oreja electrónico: ¿qué sabemos de esta poderosa herramienta de marketing? URL: https://n-economia.com /externo/1-internet-y-comercio-electronico/el-boca-oreja-electronic o-que-sabemos-de-esta-poderosa-herramienta-de-marketing/.

Wagner, M. L., Alonso, J. and Mehlhorn, A. J. (2001). 'Comparison of Internet and community pharmacies'. Annals of Pharmacotherapy 35 (1), pp. 116-119. https://doi.org/10.1345/aph.10090. 
Watts, D. J. and Dodds, P. S. (2007). 'Influentials, networks and public opinion formation'. Journal of Consumer Research 34 (4), pp. 441-458. https://doi.org/10.1086/518527.

Weimann, G., Tustin, D. H., van Vuuren, D. and Joubert, J. P. R. (2007). 'Looking for opinion leaders: traditional vs. modern measures in traditional societies'. International Journal of Public Opinion Research 19 (2), pp. 173-190. https://doi.org/10.1093/ijpor/edm005.

Weimann, G. (2016). 'The emerging role of social media in the recruitment of foreign fighters'. In: Foreign Fighters under International Law and Beyond, pp. 77-95. https://doi .org/10.1007/978-94-6265-099-2_6.

Yang, F. X. (2017). 'Effects of restaurant satisfaction and knowledge sharing motivation on eWOM intentions'. Journal of Hospitality $\mathcal{E}$ Tourism Research 41 (1), pp. 93-127. https://doi.org/10.1177/1096348013515918.

\section{Authors}

Zahaira Fabiola González Romo. Lecturer, Universitat Internacional de Catalunya. Ph.D. in Advertising and Public Relations from the AUB, Spain. Professor of Advertising, Marketing and Public Relations at several universities (UIC, UVIC, UOC, UPC CITM, UEMC, Tecnocampus, Mediterrani and ESERP). She has given lectures, seminars and workshops in the field of marketing and advertising in several countries and has published numerous articles and books. At the moment her research is about consumer behaviour, digital marketing and fashion.

E-mail: zfgonzalez@uic.es.

Sofia Iriarte Aguirre. Universitat Internacional de Catalunya Degree student. Research lines in communication, marketing, advertising and social networks. E-mail: ca107669@uic.es.

Irene García Medina. Glasgow Caledonian University. Lecturer in Marketing at the Caledonian University of Glasgow (U.K.). Area of interest in research: mobile marketing, digital marketing, digital communication, social media, e-branding. Bachelor of Communication Sciences (Universidad Complutense de Madrid, Spain) and Ph.D. in Marketing (University of Sophia - Antipolis, France) and International Relations (University of Vienna, Austria). As a teacher, Irene has previously taught Marketing and International Business Management at graduate level and master's degree in different Universities. As a professional, she has worked as Marketing Director and as Head of Communication and Promotion of CORDIS (European Commission, DGXIII, Luxembourg).

E-mail: Garcia2@gcu.ac.uk.

How to cite

González Romo, Z. F., Iriarte Aguirre, S. and García Medina, I. (2020).

'Pharmaceutical influencers on Instagram and their communication during the Covid-19 pandemic crisis'. JCOM 19 (05), A04.

https://doi.org/10.22323/2.19050204.

(C) The Author(s). This article is licensed under the terms of the Creative Commons Attribution - NonCommercial — NoDerivativeWorks 4.0 License.

ISSN 1824-2049. Published by SISSA Medialab. jcom.sissa.it 